\title{
UPAYA PENGENDALIAN STUNTING MELALUI EDUKASI POLA MAKAN SEHAT DAN SEIMBANG SELAMA SERIBU HARI PERTAMA KEHIDUPAN
}

\author{
Meilani Kumala', Alexander Halim², Susy Olivia Lontoh ${ }^{3}$ dan Sari Mariyati Dewi ${ }^{4}$
}

\author{
${ }^{1}$ Bagian Gizi, Fakultas Kedokteran Universitas Tarumanagara \\ Email: meilanik@fk.untar.ac.id \\ ${ }^{2}$ Bagian Gizi, Fakultas Kedokteran Universitas Tarumanagara \\ Email: alexanders@fk.untar.ac.id \\ ${ }^{3}$ Bagian Fisiologi, Fakultas Kedokteran Universitas Tarumanagara \\ Email: susyo@fk.untar.ac.id \\ ${ }^{4}$ Bagian Histologi, Fakultas Kedokteran Universitas Tarumanagara \\ Email: sarid@fk.untar.ac.id
}

\begin{abstract}
Stunting or short stature is one of the nutritional problems in toddlers in the world, especially in developing countries. The results of Survei Status Gizi Balita Indonesia in 2019 showed the prevalence of stunting in Indonesia reached $27.7 \%$ which indicates stunting is still a moderate problems. The impact of stunting can affect the increased rates of morbidity and mortality in toddlers, also the decrease quality of life in adulthood. Various factors can influence stunting related to chronic malnutrition during the first 1,000 days of life covering the fetal period in the womb up to the first two years of life. This period is a rapid growth period and does not occur in the next age group, therefore adequate nutritional intake is very important at this period. Tomang subdistrict which is a partner of FK UNTAR islocated in the West Jakarta area where, the RISKESDAS Report of DKI Jakarta Province 2018, showed that the percentage of very short stature and short stature is $12,87 \%$ of toddlers in the West Jakarta area. The first step to reducing and control the prevalence of stunting has been conducted an education about Healthy and Balanced Diet During the First Thousand Days to cadres in the village of Toman, West Jakarta. The activity showed that most cadres experienced increased knowledge about healthy food intake and balanced nutrition after getting based on preposttests of education. The achieved results need to be followed up with training and mentoring so that the cadres are always motivated and renew their knowledge related to stunting management. So, they can carry out their duties thus can contribute to reducing the prevalence of stunting in toddlers.
\end{abstract}

Keywords: Stunting, the first 1,000 days of life, healthy foods, balance nutrition

\begin{abstract}
ABSTRAK
Stunting atau pendek merupakan salah satu masalah gizi yang dialami oleh balita di dunia terutama di negara sedang berkembang. Survei Status Gizi Balita Indonesia tahun 2019 menunjukkan prevalensi stunting di Indonesia mencapai 27,7\% yang menunjukkan stunting di Indonesia masih merupakan masalah dengan kategori tingkat sedang. Dampak stunting pada balita dapat berakibat meningkatnya angka kesakitan dan kematian pada bayi dan balita, serta menurunnya kualitas hidup di usia dewasa. Berbagai faktor dapat memengaruhi terjadinya stunting terkait kekurangan gizi kronis selama 1.000 hari pertama kehidupan (HPK) anak yang meliputi masa janin dalam kandungan sampai dua tahun setelah kelahiran. Masa HPK merupakan masa proses tumbuh kembang yang sangat cepat dan tidak terjadi pada kelompok usia selanjutnya, oleh karena itu pemenuhan asupan gizi pada masa ini sangat penting. Kelurahan Tomang yang merupakan mitra FK UNTAR terletak di daerah Jakarta Barat dimana berdasarkan Laporan RISKESDAS Provinsi DKI Jakarta 2018, menunjukkan kejadian sangat pendek dan pendek sebesar 12,87\% pada usia bawah dua tahun di wilayah Jakarta Barat. Sebagai langkah awal untuk pencegahan dan pengendalian terjadinya stunting, telah dilakukan edukasi mengenai Pola Makan Sehat dan Seimbang Selama HPK kepada para kader di kelurahan Tomang, Jakarta Barat. Kegiatan edukasi tersebut menunjukkan sebagian besar kader mengalami peningkatan pengetahuan tentang asupan makanan sehat dan gizi seimbang setelah mendapat edukasi berdasarkan pre-pos tes. Hasil yang dicapai ini perlu dilakukan tindak lanjut dengan pelatihan dan pendampingan agar para kader selalu termotivasi dan memperbaharui pengetahuan terkait pengendalian stunting dalam menjalankan tugasnya dengan demikian dapat berkontribusi dalam upaya menurunkan angka kejadian stunting pada balita.
\end{abstract}

Kata kunci: Stunting, 1000 hari pertama kehidupan, Makanan sehat, Gizi seimbang

\section{PENDAHULUAN}

Stunting atau pendek merupakan salah satu masalah gizi yang dialami oleh balita di dunia terutama di negara sedang berkembang. Di dunia, tercatat secara global terdapat 149,2 juta (22\%) anak 
balita mengalami stunting pada tahun 2018 dan diperkirakan akan bertambah jumlahnya secara substansial disebabkan kendala dalam mendapatkan nutrisi yang sesuai kebutuhan selama pandemik COVID-19. (United Nations Children's Fund, 2021). Berdasarkan WHO Global Database on Child Growth pada tahun 1993, masalah stunting dapat ditetapkan menjadi empat kategori stunting yaitu sebagai suatu masalah ringan/rendah bila prevalensinya $<20 \%$; kategori masalah sedang yaitu 20-29\%; merupakan masalah tinggi/berat bila prevalensi stunting 30-39\% dan sangat berat bila $\geq 40 \%$. (de Onis M, Monteiro C, Akre J, Clugston G, 1993: WHO 2019) Di Indonesia, berdasarkan laporan Riset Kesehatan Dasar (RISKESDAS) Kementerian Kesehatan 2018, prevalensi stunting Balita di Indonesia sudah mengalami penurunan dari 37,2\% pada tahun 2013 menjadi 30,8\% pada tahun 2018. (RISKEDAS 2018) Hasil Survei Status Gizi Balita Indonesia (SSGBI) pada tahun 2019 menunjukkan bahwa prevalensi stunting di Indonesia sudah menurun mencapai $27,7 \%$, namun angka ini masih termasuk kategori masalah sedang berdasarkan kategori stunting. Pemerintah menargetkan melalui Rencana Pembangunan Jangka Menengah Nasional (RPJMN) 2020-2024 angka stunting menurun mencapai 14\%. (Kementerian Kesehatan RI, 2020)

Stunting dapat memberi dampak terhadap kualitas hidup baik dampak jangka pendek dan jangka panjang. Dampak jangka pendek mencakup antara lain meningkatnya angka kesakitan (morbidtas) dan kematian (mortalitas) pada bayi dan anak, terganggunya perkembangan kognitif, motorik dan verbal, dan meningkatnya biaya kesehatan akibat stunting. Dampak jangka panjang yang disebabkan oleh stunting antara lain postur tubuh yang tidak optimal di usia dewasa, meningkatnya risiko obesitas dan penyakit lainnya, menurunkan kesehatan reproduksi pada anak perempuan, kapasitas dan performa belajar yang tidak optimal selama masa sekolah, dan produktifitas dan kapasitas kerja yang tidak optimal. (Stewart et.al, 2013)

Stunting terjadi oleh karena terdapatnya kekurangan gizi kronis selama 1.000 hari pertama kehidupan anak (HPK) yang meliputi masa janin dalam kandungan sampai dua tahun setelah kelahiran. Masa HPK ini merupakan masa proses tumbuh kembang yang sangat cepat dan tidak terjadi pada kelompok usia selanjutnya, oleh karena itu pemenuhan asupan gizi pada masa ini sangat penting. Status gizi ibu selama masa sebelum hamil, penambahan berat badan dan kesehatan selama masa kehamilan merupakan faktor yang perlu mendapat perhatian. Asupan makanan sesuai kebutuhan kalori, protein, lemak dan mikronutrien merupakan faktor penting dalam pertambahan berat badan ibu selama kehamilan. Asupan gizi yang tidak memadai, pemberian air susu ibu (ASI) suboptimal dan pemberian makanan pelengkap yang terbatas dalam jumlah, kualitas, dan variasi pada masa bayi dan anak usia dini juga merupakan faktor yang berkontribusi terjadinya stunting. (Stewart CP et.al, 2013) Penyakit infeksi klinis dan subklinis yang terjadi dalam 2 tahun pertama kehidupan terutama jika tidak ada asupan adekuat yang mendukung pemulihan, juga merupakan faktor yang dapat mengakibatkan gangguan pertumbuhan linier. Kebersihan lingkungan juga turut berperan dalam terjadinya stunting dimana lingkungan yang terkontaminasi dan higienitas yang buruk dapat menyebabkan terganggunya penyerapan zat gizi dan turunnya pertahanan saluran cerna. (Dewey \& Begum, 2011; Siregar et al., 2011)

Berdasarkan dampak yang akan dialami anak stunting dan faktor yang memengaruhi kejadian stunting, pencegahan dan pengendalian stunting pada balita perlu dilakukan secara terkoordinir dari berbagai aspek terkait faktor yang memengaruhi terjadinya stunting. Salah satu aspek yang dapat dilakukan meliputi memberi pengertian pentingnya asupan gizi yang adekuat pada ibu selama kehamilan dan pemberian gizi yang cukup dalam jumlah dan kualitas kepada anaknya pada usia dua tahun pertama kelahiran. Ibu selama kehamilan membutuhkan asupan kalori dan zat gizi yang lebih banyak dibandingkan dengan keadaan tidak hamil untuk memenuhi kebutuhan ibunya, 
pertumbuhan dan perkembangan janin dalam kandungan serta persiapan memrodruksi ASI. Air susu ibu merupakan makanan terbaik dalam memenuhi semua zat gizi yang dibutuhkan untuk perkembangan sistem pencernaa, murah dan bersih pada bayi usia 0-6 bulan. (Kementerian Kesehatan RI, 2014)

Menurut laporan Riset Kesehatan Dasar (Riskesdas) Provinsi DKI Jakarta tahun 2018, didapatkan kejadian pendek di wilayah Jakarta Barat adalah 5,8\% dan sangat pendek adalah 7,07\%. (Tim Riskesdas 2018, 2019) Wilayah kelurahan Tomang merupakan daerah mitra Fakultas Kedokteran Universitas Tarumanagara serta daerah Tomang yang terletak di Jakarta Barat. Kelurahan Tomang memiliki luas wilayah $1.88 \mathrm{~km} 2$, terdiri dari 8,841 kepala keluarga (KK), $16 \mathrm{RW}$ (rukun warga) dan 174 RT (rukun tetangga). Di Wilayah ini terdapat sejumlah 227 anak anak usia 0-12 bulan dan sebanyak 677 anak usia 13-60 bulan dari 16 RW. (Data Kader Kelurahan Tomang). Berdasarkan permasalahan dan dampak yang diuaraikan di atas maka perlu dilakukan upaya preventif dan pengendalian terjadinya Stunting di daerah tersebut. Sebagai bentuk nyata telah dilakukan edukasi terkait pola makan sehat dan seimbang selama seribu hari pertama kehidupan. Edukasi yang dilaksanakan adalah kepada para kader kelurahan Tomang, Jakarta Barat, diharapkan dapat diperluas edukasi kepada masyarakat pasangan usia subur setempat oleh para kader.

\section{METODE PELAKSANAAN PKM}

\subsection{Persiapan pelaksanaan}

Pelaksanaan kegiatan edukasi tentang pengendalian stunting kepada para kader Kelurahan Tomang Jakarta Barat dilakukan dalam beberapa tahap meliputi:

- Eksplorasi tingkat prevalensi Stunting berdasarkan survei dan bukti/data kegiatan pengabdian kepada masyarakat (PKM) dan penelitian sebelumnya,

- Survei lapangan: survei ke kantor kelurahan Tomang, Jakarta Barat (melalui zoom) untuk mendapatkan data terkait permasalahan kesehatan dan status gizi ibu dan anak,

- Penyusunan Proposal: berdasarkan data dari hasil survei disusun proposal, topik dan pembicara yang sesuai topik permasalahan,

- Rancangan pelaksanaan: rancangan materi edukasi dan materi pre/pos tes sebagai umpan balik dari kegiatan edukasi,

- Rapat persiapan finalisasi hari pelaksanaan, pelaksanaan dan rapat evaluasi pelaksanaan seperti yang ditunjukan pada Gambar 1 .

\section{Gambar 1}

Rapat Finalisasi Persiapan Pelaksanaan

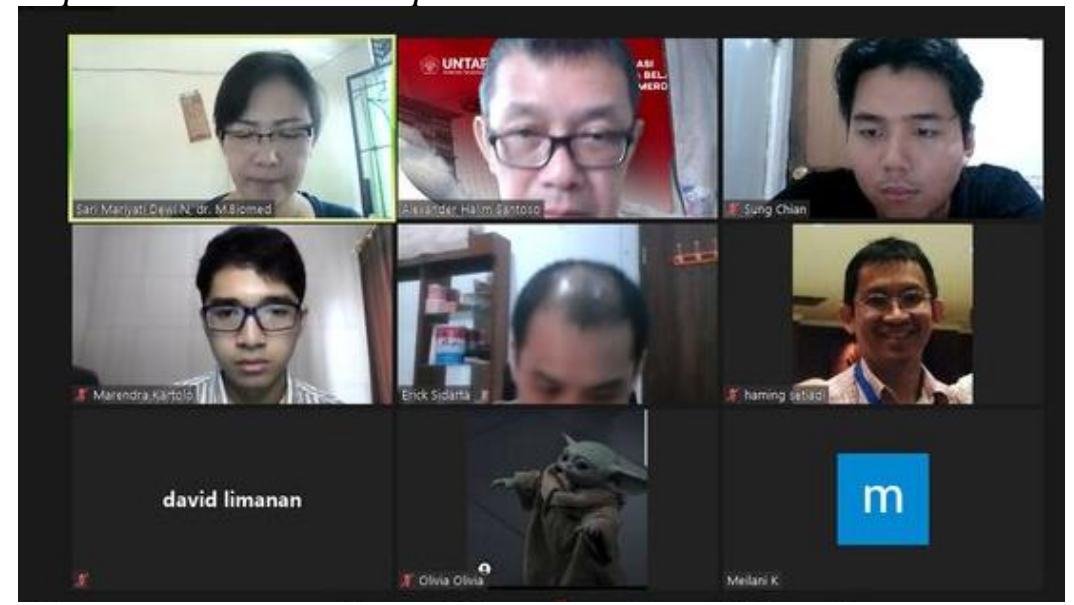

Gambar 2 


\section{Alur Pelaksanaan Edukasi kepada Para Kader}
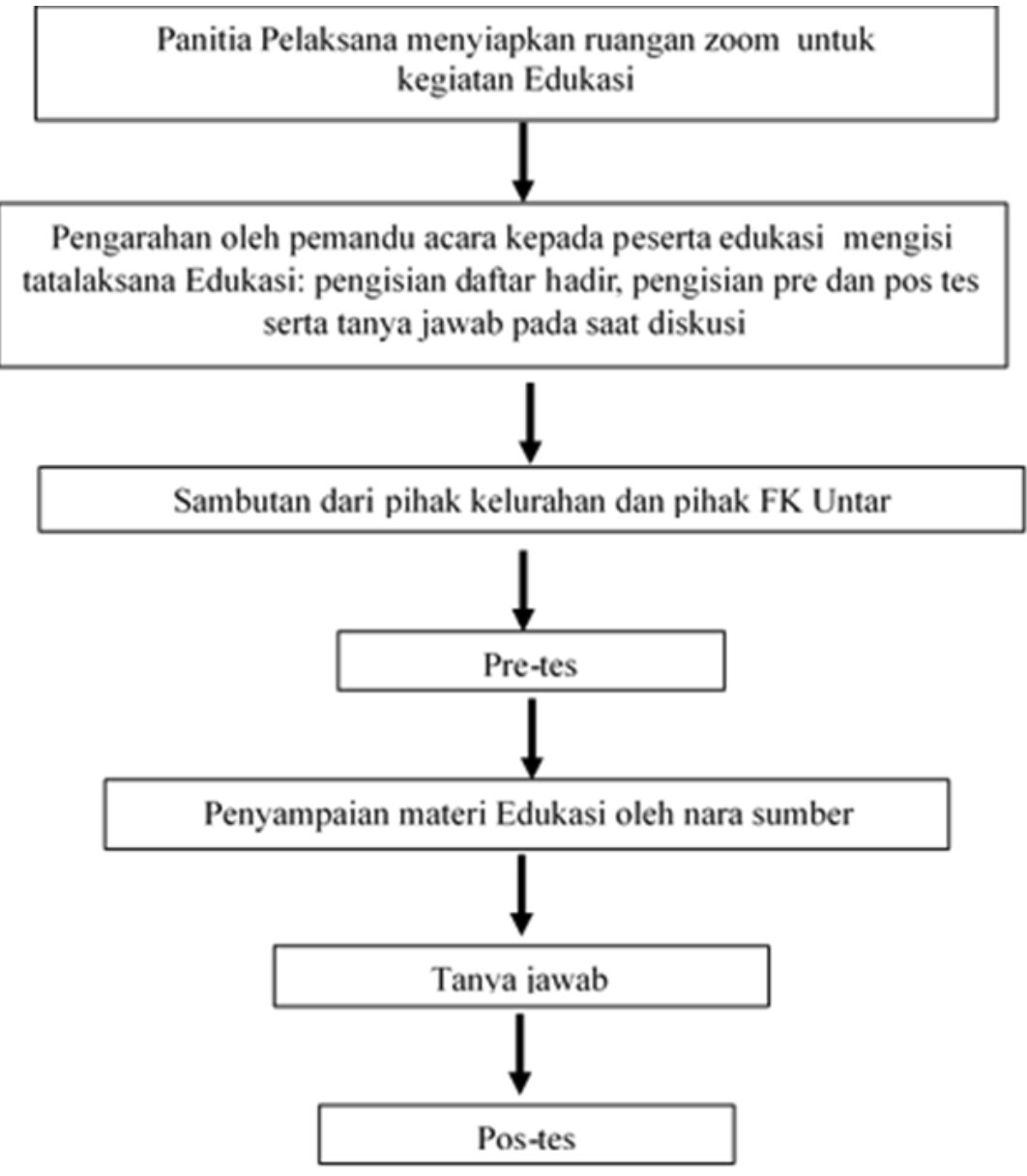

\section{Gambar 3}

Pelaksanaan Edukasi Pengendalian Stunting kepada Para Kader Kelurahan Tomang Jakarta

\section{Barat}

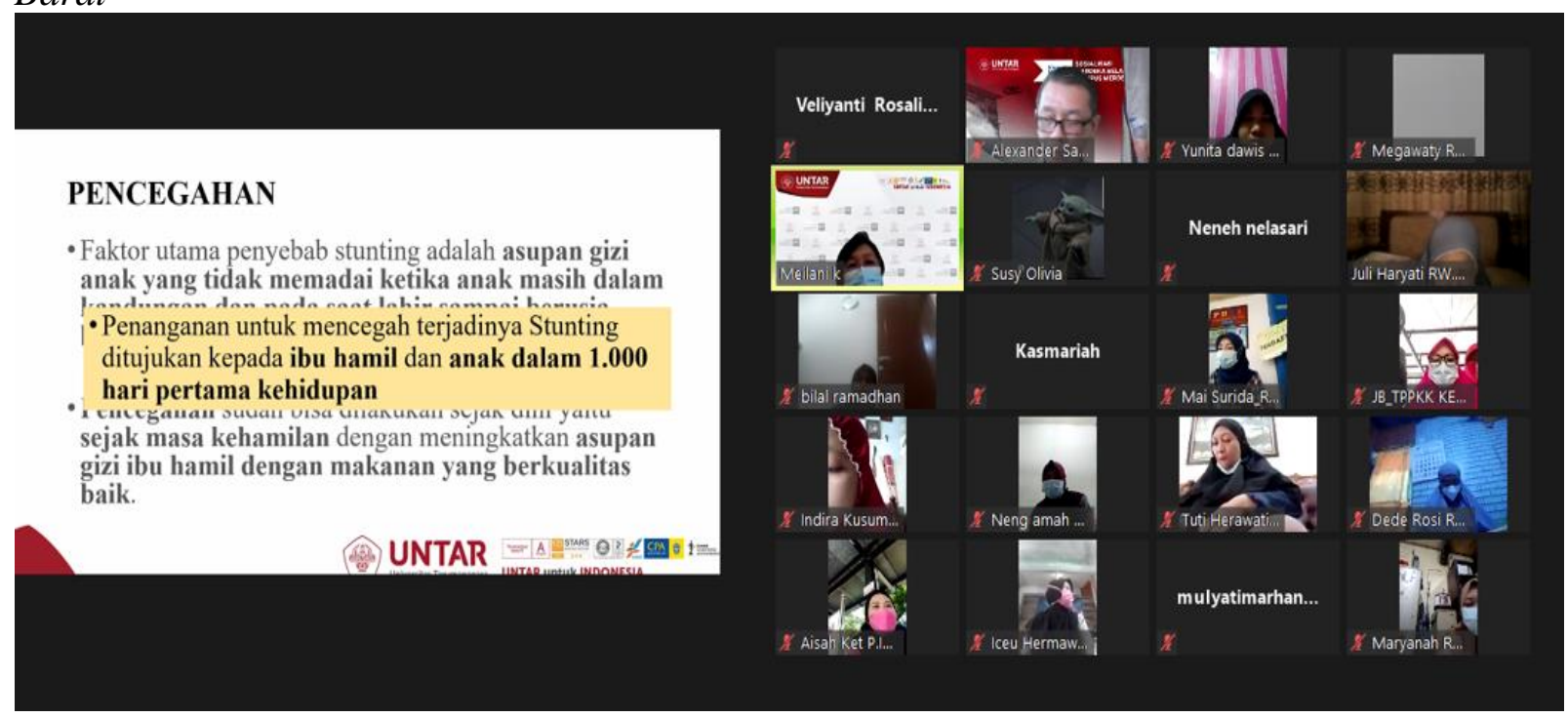

\subsection{Pelaksanaan kegiatan}


Pelaksanaan kegiatan edukasi dilakukan melalui zoom dengan alur pelaksanaan seperti pada gambar 2. Acara diselenggarakan pada hari Kamis, tanggal 27 Juli, jam 8.00-12.00 WIB dengan susunan acara pertama-tama sambutan dari pihak kelurahan dan pihak FK Untar dan dilanjutkan pre tes untuk mengetahui tingkat pengetahuan mengenai materi edukasi yang akan disampaikan. Kegiatan dilanjutkan dengan penyampaian materi dari nara sumber dan setelah penyampaian materi kembali dilakukan pos tes untuk mengetahui capaian pengetahuan dari para kader setelah mendapat materi.

\section{HASIL DAN PEMBAHASAN}

Kegiatan edukasi tentang pengendalian Stunting kepada para kader Kelurahan Tomang Jakarta Barat telah dilaksanakan pada hari Kamis, tanggal 27 Juli, jam 8.00-12.00 WIB dengan dihadiri 42 kader. Pelaksanaan edukasi di awali dengan pre tes. Seluruh peserta melakukan pre tes dan didapatkan lebih dari lima puluh persen $(57,1 \%)$ peserta belum memadai pengetahuannya terkait Stunting.

Penyampaian materi oleh nara sumber adalah mengenai kesehatan terkait pengendalian terjadinya stunting melalui asupan gizi yang adekuat selama 1000 hari pertama kelahiran yaitu asupan gizi yang adekuat sesuai kebutuhan bagi ibu selama masa kehamilan, bayi dan anak usia dini. (Gambar 3) Asupan gizi ibu selama kehamilan yang dianjurkan sesuai dengan tiga belas menu gizi seimbang ditambah dengan pesan khusus Pesan Gizi Seimbang untuk ibu hamil yaitu konsumsi aneka ragam makanan; batasi mengkonsumsi garam; minum air putih yang banyak dan batasi minum kopi. (Gambar 4) (Kementerian Kesehatan RI, 2014)

Ibu selama kehamilan perlu mengonsumsi aneka ragam pangan lebih banyak agar tercapai pemenuhan kebutuhan energi, protein, vitamin dan mineral untuk pemeliharaan, pertumbuhan dan perkembangan janin dalam kandungan serta cadangan selama masa menyusui. Membatasi makan makanan yang mengandung garam tinggi untuk mencegah terjadinya hipertensi selama kehamilan. Minum air putih lebih banyak selama kehamilan sekitar 2-3 liter perhari (8-12 gelas sehari) dengan tujuan mendukung sirkulasi janin, produksi cairan amnion dan meningkatnya volume darah. Selama kehamilan ibu harus membatasi minum kopi paling banyak 2 cangkir kopi/hari untuk menghindari terjadinya dehidrasi, meningkatnya tekanan darah dan detak jantung yang meningkat.

\section{Gambar 4}

Tumpeng Gizi Seimbang Panduan Konsumsi Sehari Hari

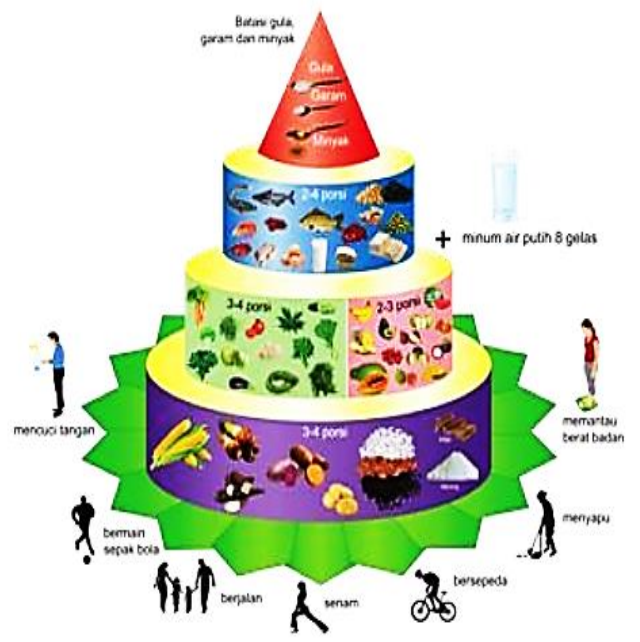

\section{Gambar 5}




\section{Grafik Hasil Kuesioner Pre dan Pos Tes}

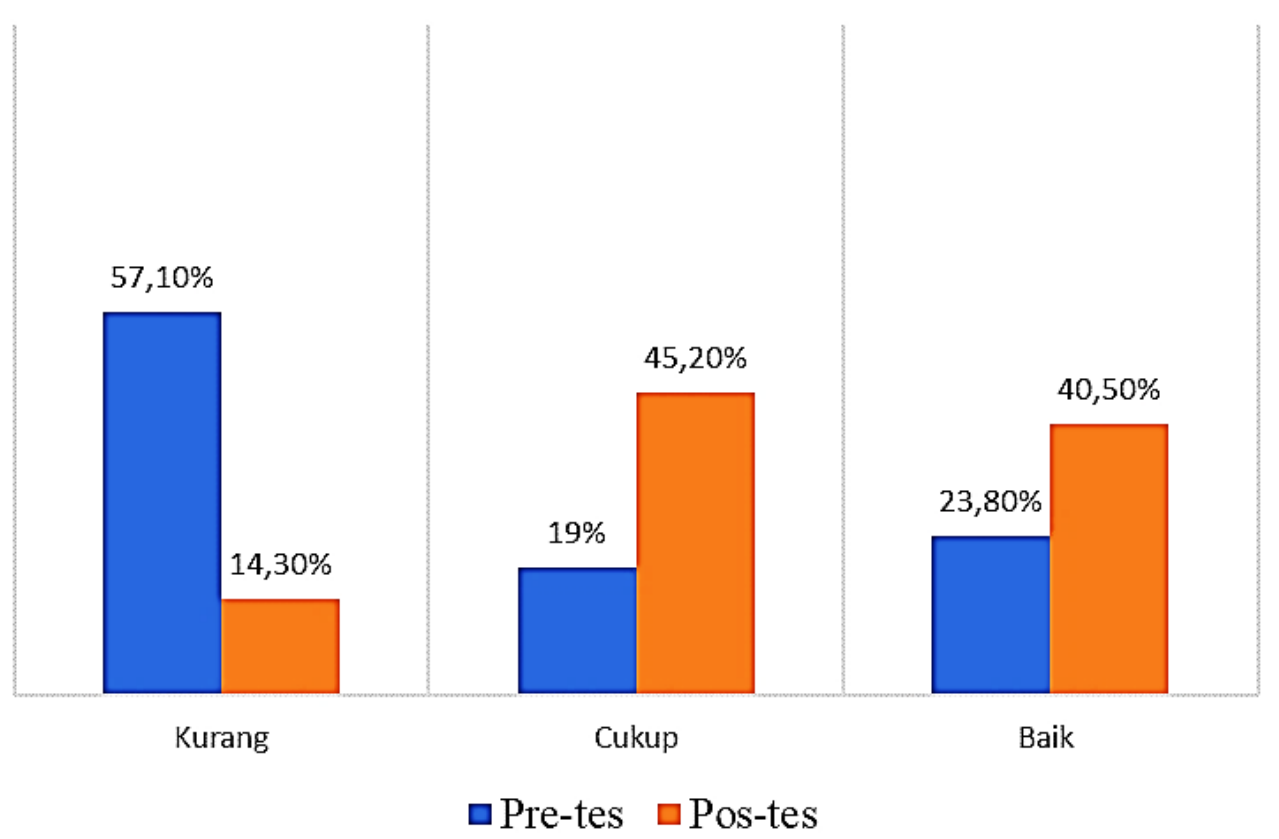

Asupan gizi untuk bayi 0-6 bulan dicukupi dengan pemberian Air Susu Ibu (ASI). Air susu ibu merupakan makanan yang sesuai untuk memenuhi semua zat gizi yang dibutuhkan, murah dan bersih. Selama usia 0-6 bulan bayi harus memperoleh ASI eksklusif yaitu hanya mendapat ASI dan tidak mendapatkan makanan atau minuman lain. Pencapaian kecukupan ASI untuk gizi bayi harus dimulai dengan melakukan Inisiasi Menyusui Dini (IMD) yaitu proses memberikan ASI dimulai secepatnya setelah bayi dilahirkan. Asupan gizi untuk anak usia 6-24 bulan selain mendapat ASI, sudah harus mendapatkan Makanan Pendamping ASI (MP-ASI). Anak pada usia 6-24 bulan kebutuhan zat gizi meningkat oleh karena pada masa ini terjadi pertumbuhan dan perkembangan yang cepat dan anak secara fisik sudah mulai aktif. Pemberian MP-ASI dimulai dengan pemberian makanan dalam bentuk lumat, makanan lembik dan beralih ke makanan keluarga pada saat berusia satu tahun.

Materi edukasi juga mencakup bagaimana melakukan deteksi dini bagi Ibu hamil dan anak usia dini meliputi penimbangan berat badan secara teratur untuk ibu selama masa kehamilan dan anak usia dini. Pantauan dan diteksi dini status gizi pada bayi dan anak usia dini dilakukan dengan penimbangan berat badan (BB) dan tinggi badan (TB) setiap bulan dan dicatat, dibuat ploting dalam kurva kartu pertumbuhan WHO 2006 meliputi kurva berat badan terhadap umur (BB/U), tinggi badan terhadap umur $(\mathrm{TB} / \mathrm{U})$, berat badan terhadap tinggi badan $(\mathrm{BB} / \mathrm{TB})$. Pada kesempatan edukasi dilakukan penjelasan mengenai pencatatan hasil penimbangan berat badan dan tinggi badan pada grafik pertumbuhan.

Setelah edukasi selesai, kepada peserta diberi kesempatan untuk bertanya dan diskusi dengan nara sumber. Acara dilanjutkan dengan dilakukan pos tes dengan soal yang sama dengan soal pre tes. Hasil pos-tes didapatkan perubahan dimana terjadi peningkatan persentase kader dengan hasil yang sebelumnya baik dan cukup serta penurunan persentase kader dengan hasil jawaban nilai yang kurang seperti terlihat dalam Gambar 5.

\section{KESIMPULAN dan SARAN}


Kegiatan edukasi kepada para Kader Kelurahan Tomang, Jakarta Barat telah dilaksanakan dan menunjukkan terjadi peningkatan pengetahuan dan pemahaman mengenai pola makan sehat dan seimbang selama seribu hari pertama kehidupan terkait pengendalian terjadinya stunting. Berdasarkan hasil pre dan pos tes didapatkan penurunan persentase yang kurang mengerti pada pre tes sebesar $57,1 \%$ menjadi $14,3 \%$ setelah edukasi dan terjadi peningkatan persentase yang sudah mengerti pada pre tes dari $23,8 \%$ menjadi $40,5 \%$ pada pos tes. Hasil yang dicapai ini perlu dilakukan tindak lanjut dengan pelatihan-pelatihan dan pendampingan lebih lanjut agar para kader dapat menjalankan tugasnya dengan penuh semangat dan tanggung jawab sehingga dapat berkontribusi dalam upaya menurunkan angka kejadian stunting pada balita.

\section{Ucapan Terima Kasih (Acknowledgement)}

Tim PKM mengucapkan terima kasih kepada Yayasan Tarumanagara, Bapak Rektor Universitas Tarumanagara, Ketua Lembaga Penelitian dan Pengabdian kepada Masyarakat Universitas Tarumanagara, dan Pimpinan Fakultas Kedokteran Universitas Tarumanagara atas dukungan yang diberikan mulai dari persiapan sampai penyelenggaraan kegiatan pengabdian ini. Kami juga mengucapkan terima kasih untuk dukungan, bantuan dan kerjasama dari Ibu Lurah dan masyarakat Kelurahan Tomang Jakarta Barat khususnya para kader yang sudah berpartisipasi dalam kegiatan ini.

\section{REFERENSI}

United Nations Children's Fund (UNICEF), World Health Organization \& International Bank for Reconstruction and Development/The World Bank. (2021). Levels and trends in child malnutrition: key findings of the 2021 edition of the joint child malnutrition estimates. World Health Organization.

de Onis, M., Monteiro C, Akre J \& Clugston G. (1993). The worldwide magnitude of proteinenergy malnutrition: an overview from the WHO Global Database on Child Growth. Bull World Health Organ 71.

Nutrition Landscape Information System (NLiS). (2019). Country profile indicators: interpretation guide, second edition. World Health Organization.

Riset Kesehatan Dasar (Riskesdas) (2018). Badan Penelitian dan Pengembangan Kesehatan Kementerian RI.

Sekretariat Kabinet RI Deputi Bidang Perekonomian. (2020). Rencana pembangunan jangka menengah nasional 2020-2024 (peraturan presiden RI nomor 18 tahun 2020). https://drive.bappenas.go.id/ owncloud/index.php /s/4q7Cb7FBxavq31K

Stewart, C.P., Iannotti, L., Dewey, K.G., Michaelsen, K.F. \& Onyango, A.W. (2013). Contextualising complementary feeding in a broader framework for stunting prevention. Maternal and Child Nutrition, 9(Suppl 2), 27-45.

Dewey, K. G., \& Begum, K. (2011). Long-term consequences of stunting in early life. Maternal and Child Nutrition, 7(SUPPL. 3), 5-18. https://doi.org/10.1111/j.1740-8709.2011.00349.x

Siregar, R., Lilisianawati, L., Lestari, E. D., \& Salimo, H. (2011). Effect of zinc supplementation on morbidity among stunted children in Indonesia. Paediatrica Indonesiana, 51(3), 128. https://doi.org/10.14238/pi51.3.2011.128-32

Kementerian Kesehatan RI. (2014). Pedoman gizi seimbang.

Tim Riskesdas 2018. (2019). Laporan Provinsi DKI Jakarta Riskesdas 2018. Lembaga Penerbit Badan Penelitian dan Pengembangan Kesehatan

Pedoman Umum Pengelolaan Posyandu. (2011). Kementerian Kesehatan Rl. 